\title{
Penerapan Model Pembelajaran Problem Solving untuk Meningkatkan Hasil Belajar IPA Siswa Kelas V
}

\author{
Pri Subekti
}

\section{SDN 2 Gembleb Kecamatan Pogalan Kabupaten Trenggalek Email prisubektigembleb2@gmail.com}

\section{Tersedia Online di}

http://www.jurnal.unublitar.ac.id/ index.php/briliant

\section{Sejarah Artikel}

Diterima pada 2 April 2017

Disetuji pada 4 April 2017

Dipublikasikan pada 1 Mei 2017

Hal. $130-139$

\section{Kata Kunci:}

Pembelajaran ipa, problem solving

\begin{abstract}
Abstrak: Melalui penerapan model pembelajaran problem solving, siswa akan aktif melakukan percobaan untuk memecahkan masalah sehingga aktivitas dan hasil belajar siswa dalam memecahkan masalah meningkat. Penelitian ini termasuk penelitian tindakan kelas dengan pendekatan kualitatif interaktif yang dilakukan secara bersiklus. Prosentase ketuntasan hasil belajar klasikal siklus-2 yaitu $100 \%$ dengan nilai rata-rata hasil belajar kelas 90,04. Penerapan model pembelajaran problem solving pada pembelajaran IPA materi pokok pengungkit di kelas V SDN 2 Gembleb Kecamatan Pogalan Kabupaten Trenggalek dapat diterapkan dengan baik sekali.
\end{abstract}

Pendidikan merupakan hal yang sangat berpengaruh dalam meningkatkan kemajuan suatu bangsa. Kualitas pendidikan yang bagus akan dapat membantu menciptakan SDM yang berkualitas. SDM yang berkualitas akan dapat meningkatkan kemajuan bangsa. Untuk itu dalam upaya meningkatkan kesiapan SDM yang mampu menghadapi perkembangan ilmu pengetahuan dan teknologi diperlukan perbaikan secara terus-menerus khususnya pada bidang pendidikan.

Pendidikan merupakan proses interaksi yang mendorong terjadinya belajar (Dimyati \& Mudjiono, 2006:7). Proses interaksi yang mendorong terjadinya belajar merupakan suatu kegiatan yang direncanakan untuk merangsang siswa melakukan aktivitas untuk menemukan pengetahuannya. Dengan menemukan sendiri pengetahuannya maka pengetahuan siswa akan bertahan lama dan dapat digunakan dalam kehidupan sehari-hari siswa. Dengan demikian belajar akan menjadi bermakna bagi siswa. Terciptanya proses pembelajaran yang bermakna sangat tergantung pada kesiapan dan kemampuan serta kreativitas guru dalam menerapkan berbagai model pembelajaran.

Model pembelajaran yang memberikan kesempatan kepada siswa terlibat secara aktif dapat mengembangkan potensi siswa secara menyeluruh. Artinya tidak hanya pengetahuan saja yang bertambah, melainkan keterampilan dan sikap ilmiah siswa juga dapat berkembang secara optimal. Hal ini menyatakan bahwa hasil belajar yang dicapai sangat tergantung pada kegiatan pembelajaran yang diterapkan.

Kegiatan pembelajaran merupakan kegiatan yang terdiri dari kegiatan belajar dan mengajar. Kedua kegiatan tersebut saling berkaitan. Kegiatan belajar dan mengajar harus dilaksanakan dengan baik agar dapat membantu meningkatkan kualitas hasil belajar. 
Hasil belajar dipengaruhi oleh stimulasi lingkungan yang ada. Stimulasi lingkungan tersebut dapat terjadi secara alamiah ataupun yang sengaja dibuat guru, misalnya melalui model pembelajaran yang diterapkan. Melalui penerapan model pembelajaran yang menarik akan dapat merangsang siswa untuk senang belajar.

Pelaksanaan kegiatan pembelajaran saat ini masih banyak belum mengaktifkan siswa. Hal itu, seharusnya dihindari karena akan dapat menghambat kreativitas siswa dalam menemukan pengetahuannya. Pengetahuan yang diperoleh siswa tidak akan bermakna dan cepat hilang. Kondisi pelaksanaan pendidikan yang didominasi guru juga terjadi di SD dalam pembelajaran IPA. Tentu saja kondisi seperti itu sangat bertentangan dengan karakteristik pembelajaran IPA.

Ilmu pengetahuan alam (IPA) berhubungan dengan cara mencari tahu tentang alam secara sistematis, sehingga IPA bukan hanya penguasaan kumpulan pengetahuan yang berupa fakta-fakta, konsep-konsep atau prinsip-prinsip saja tetapi juga suatu proses penemuan (Depdiknas, 2006:484). Berdasarkan pengertian IPA tersebut tampak bahwa dalam kegiatan pembelajaran IPA guru harus merangsang siswa untuk aktif melakukan kegiatan misalnya melalui penerapan model pembelajaran yang dapat mengaktifkan siswa melalui percobaan-percobaan dalam memecahkan masalah. Hal itu sesuai dengan tahap perkembangan kognitif siswa SD. Percobaan-percobaan dalam memecahkan masalah yang dilakukan siswa akan membuat siswa termotivasi mengikuti kegiatan pembelajaran. Siswa akan menjadi aktif sehingga kegiatan pembelajaran tidak membosankan. Selain itu siswa akan lebih mudah memahami materi pembelajaran.

Dari hasil pengamatan, diperoleh temuan secara faktual bahwa kegiatan pembelajaran IPA umumnya masih monoton. Fenomena ini juga ditemui dalam Kegiatan pembelajaran IPA yang masih monoton juga ditemui dalam pelaksanaan kegiatan pembelajaran IPA di SDN 2 Gembleb Kecamatan Pogalan Kabupaten Trenggalek. Berdasarkan hasil observasi yang dilakukan peneliti pada tanggal 22 Januari 2013 diperoleh temuan bahwa kegiatan pembelajaran IPA materi pokok pengungkit di SDN 2 Gembleb Kecamatan Pogalan Kabupaten Trenggalek masih bersifat ceramah dan tanya jawab pelaksanaan pembelajarannya kurang menarik karena guru yang sekaligus menjadi peneliti tidak menerapkan model pembelajaran yang bervariasai. Akibat dari hal ini menyebabkan minat siswa untuk belajar menjadi rendah.

Selain itu, peneliti juga memperoleh kesimpulan bahwa pelaksanaan kegiatan pembelajaran masih dilakukan dengan menggunakan metode ceramah. Siswa hanya mendengarkan penjelasan dari guru tanpa ada kegiatan untuk melakukan percobaan. Selain itu, guru yang sekaligus menjadi peneliti menyadari bahwa pembelajaran yang dterapkan selama ini tidak menerapkan model pembelajaran yang dapat mengaktifkan siswa. Kadang-kadang, guru dalam pembelajaran IPA hanya menggunakan media gambar. Gambar yang digunakan hanya terbatas pada gambar yang ada di buku IPA kelas V.

Berdasarkan hasil wawancara yang dilakukan dengan beberapa siswa kelas V SDN 2 Gembleb Kecamatan Pogalan Kabupaten Trenggalek, diungkapkan bahwa kegiatan pembelajaran menjenuhkan karena guru hanya ceramah saja. Siswa menyatakan lebih senang jika diberi kesempatan untuk melakukan percobaan-percobaan. 
Rendahnya hasil belajar siswa dapat dilihat pada nilai hasil tes siswa yang dilakukan pada pra tindakan pra tindakan. Dari hasil tes menunjukkan bahwa tingkat pemahaman dan kemampuan siswa dalam memecahkan masalah yang berkaitan dengan berbagai fungsi pengungkit masih rendah. Dari 19 siswa hanya 4 siswa yang mendapat nilai 75-100, sedangkan 8 siswa yang mendapat nilai 50-74 dan 7 siswa mendapat nilai di bawah 50. Dari nilai hasil belajar siswa tersebut, diketahui bahwa hasil belajar IPA siswa kelas V SDN 2 Gembleb Kecamatan Pogalan Kabupaten Trenggalek masih rendah atau di bawah SKM yang ditetapkan yaitu 70 .

Berdasarkan permasalahan tersebut, peneliti memiliki tujuan sebagai berikut, (1) Mendiskripsikan penerapan model pembelajaran problem solving pada pembelajaran IPA materi pokok pengungkit di kelas V SDN 2 Gembleb Kecamatan Pogalan Kabupaten Trenggalek, (2) Mendiskripsikan peningkatan aktivitas belajar siswa melalui penerapan model problem solving pada pembelajaran IPA materi pokok pengungkit siswa kelas V SDN 2 Gembleb Kecamatan Pogalan Kabupaten Trenggalek, (3) Mendiskripsikan peningkatan hasil belajar siswa setelah penerapan model problem solving pada pembelajaran IPA materi pokok pengungkit siswa kelas V SDN 2 Gembleb Kecamatan Pogalan Kabupaten Trenggalek.

Untuk memecahkan masalah rendahnya aktivitas dan hasil belajar IPA materi pokok pengungkit siswa kelas V SDN 2 Gembleb Kecamatan Pogalan Kabupaten Trenggalek maka akan dilakukan kegiatan pembelajaran dengan penerapan model pembelajaran problem solving pada pembelajaran IPA. Selama pembelajaran IPA tersebut siswa akan dilatih memecahkan masalah melalui beberapa langkah model pembelajaran problem solving. Dengan penerapan model pembelajaran problem solving, maka siswa akan lebih aktif dalam melakukan percobaan untuk memecahkan masalah yang berkaitan dengan berbagai fungsi pengungkit.

\section{METODE}

Penelitian ini dilaksanakan di SDN 2 Gembleb Kecamatan Pogalan Kabupaten Trenggalek pada siswa kelas V tahun ajaran 2012/2013. SDN 2 Gembleb terletak di alamat RT. 26 RW. 09, Dsn. Talun . Ds. Gembleb, Kec. Pogalan, Kab. Trenggalek. Letak SDN 2 Gembleb berada di lingkungan pedesaan. Dari sarana prasarana, SDN 2 Gembleb termasuk dalam kategori cukup lengkap.

Subyek dalam penelitian ini adalah siswa kelas V SDN 2 Gembleb Kecamatan Pogalan Kabupaten Trenggalek yang berjumlah 19 orang. Siswa kelas V tersebut terdiri dari 8 siswa laki-laki dan 11 siswa perempuan.

Penelitian ini dilakukan dengan menggunakan pendekatan penelitian kualitatif interaktif. Penelitian kualitatif adalah penelitian yang datanya berupa kata-kata atau pernyataan-pernyataan dan data tersebut dianalisis secara kualitatif dengan tujuan untuk menemukan makna dibalik berbagai gejala/peristiwa yang tampak (Akbar, 2010:13-14).

Interaktif adalah adanya hubungan interaksi dan komunikasi antara peneliti dengan yang diteliti dalam melakukan penelitian untuk mengatasi permasalahan yang ada. Berdasarkan penjelasan di atas, dapat dijelaskan bahwa penelitian dengan menggunakan pendekatan kualitatif interaktif adalah penelitian 
yang datanya berupa kata-kata atau pernyataan-pernyataan yang diperoleh dari pengumpulan data sesuai dengan keadaan yang sebenarnya kemudian dianalisis secara kualitatif sehingga dapat menyelesaikan masalah yang ada melalui hubungan interaktif antara peneliti dan yang diteliti.

Jenis penelitian yang digunakan dalam penelitian ini adalah penelitian tindakan kelas. Penelitian tindakan kelas adalah proses investigasi terkendali untuk menemukan dan memecahkan masalah pembelajaran di kelas, proses pemecahan masalah tersebut dilakukan secara bersiklus, dengan tujuan untuk meningkatkan kualitas dan hasil pembelajaran di kelas tertentu (Akbar, 2010:26). Penelitian tindakan kelas ini menggunakan model kolaboratif yaitu peneliti berkolaborasi dengan Ibu Murtini, S. Pd. Peneliti membuat perencanaan penelitian dan melakukan praktik pembelajaran. Peneliti mengajar IPA kelas V semester 2 materi pokok pengungkit.

Pengumpulan data dalam penelitian ini menggunakan beberapa teknik pengumpulan data. Teknik analisis data yang digunakan dalam penelitian ini yaitu teknik analisis deskriptif, baik deskriptif kuantitatif maupun deskriptif kualitatif. Teknik deskriptif kuantitatif digunakan untuk menganalisis data tentang aktivitas guru dan siswa selama kegiatan pembelajaran IPA materi pokok pengungkit dengan menerapkan model pembelajaran problem solving berlangsung dan untuk menganalisis data hasil belajar siswa IPA materi pokok pengungkit setelah melakukan kegiatan pembelajaran IPA materi pokok pengungkit dengan menerapkan model pembelajaran problem solving.

Teknik analisis data deskriptif kualitatif digunakan untuk menganalisis data pengamatan aktivitas guru dan siswa selama kegiatan pembelajaran IPA materi pokok pengungkit dengan menerapkan model pembelajaran problem solving berlangsung, fortofolio siswa, foto aktivitas siswa selama kegiatan pembelajaran IPA materi pokok pengungkit dengan menerapkan model pembelajaran problem solving berlangsung dan hasil wawancara terhadap guru dan siswa sebelum dan sesudah menerapkan model pembelajaran problem solving dalam pembelajaran IPA materi pokok pengungkit. Analisis data dilakukan setelah dilakukan pengumpulan data. Pengumpulan data meliputi data tentang penerapan model pembelajaran problem solving, aktivitas dan hasil belajar siswa IPA materi pokok pengungkit.

Penelitian ini menggunakan beberapa instrumen penelitian. Instrumen penelitian yang digunakan dalam penelitian ini antara lain, (1) Pedoman observasi digunakan sebagai instrumen penelitian teknik observasi, (2) Pedoman wawancara digunakan sebagai instrumen penelitian teknik wawancara, (3) Pedoman dokumentasi digunakan sebagai instrumen penelitian teknik dokumentasi, (3) Soal tes digunakan sebagai instrumen penelitian tes, (4) Catatan lapangan digunakan sebagai instrumen penelitian catatan lapangan.

\section{HASIL}

\section{Siklus I}

Pada siklus-1 terdapat beberapa tahapan yang dilakukan peneliti. Tahapan yang dilakukan pada siklus-1 antara lain planning (perencanaan), acting and observing (tindakan dan pengamatan), reflecting (refleksi) dan revise plan (perbaikan rencana). 


\section{Perencanaan}

Pada pra kegiatan, guru menyiapkan RPP, media pembelajaran dan lembar penilaian siswa. Setelah itu, guru memulai kegiatan pembelajaran dengan mengucapkan salam, berdo'a dan melakukan presensi kehadiran siswa. Pada siklus-1 pertemuan 1 tersebut semua siswa masuk yaitu 19 siswa.

\section{Pelaksanaan}

Pada kegiatan awal, guru melakukan apersepsi, eksplorasi materi dan eksplorasi tujuan. Kegiatan inti meliputi beberapa tahapan yang mencerminkan model pembelajaran problem solving. Tahapan tersebut meliputi (1) merumuskan masalah, (2) menganalisis masalah, (3) merumuskan hipotesis, (4) mengumpulkan data, (5) pengujian hipotesis, (6) merumuskan rekomendasi pemecahan masalah.

Pada waktu merumuskan masalah, guru menunjuk 2 siswa untuk maju ke depan mendemonstrasikan mencabut paku yang menancap di kayu dengan 2 cara yang berbeda dalam menggunakan tang. Cara yang pertama dengan posisi tangan di ujung pegangan tang dan cara yang kedua dengan posisi tangan di tengah pegangan tang. Banyak siswa yang ingin mendemonstrasikan ke depan, tetapi guru hanya menunjuk 2 siswa saja sedangkan siswa yang lainnya memperhatikan apa yang terjadi. Berdasarkan pengamatan siswa terhadap demonstrasi cara mencabut paku dengan menggunakan tang tersebut, guru bertanya jawab dengan siswa tentang permasalahan yang ada dalam menggunakan tang untuk mencabut paku yang menancap di kayu tersebut.

Kegiatan akhir dilakukan dengan melakukan simpulan, evaluasi, refleksi dan tindak lanjut. Kegiatan akhir dilakukan untuk mengetahui tentang kegiatan pembelajaran yang sudah dilakukan. Pada waktu simpulan, siswa menjawab pertanyaan guru tentang apa saja yang sudah dipelajari siswa pada kegiatan pembelajaran tersebut. Siswa menjawab pertanyaan guru bersama-sama, sehingga suasana kelas ramai. Pada waktu evaluasi, siswa diminta guru mengerjakan soal evaluasi secara individu. Ada siswa yang mengeluh "capek" dan ada pula yang mengeluh "sulit" pada waktu mengerjakan soal evaluasi.

Pada waktu refleksi, siswa hanya diam saja. Pada waktu ditanya kesulitan, kesan kegiatan pembelajaran yang telah dilakukan dan saran untuk kegiatan pembelajaran berikutnya siswa malu untuk mengungkapkan pendapatnya. Tindak lanjut yang diberikan guru terhadap kegiatan pembelajarn tersebut yaitu dengan memberikan pesan moral kepada siswa. Pesan moral tersebut berkaitan dengan cara yang benar yang seharusnya dilakukan siswa pada waktu menggunakan pengungkit golongan I yaitu tang.

\section{Pengamatan}

Penerapan model pembelajaran problem solving dapat dilihat pada lembar observasi aktivitas guru menerapkan model pembelajaran problem solving, pedoman wawancara dan catatan lapangan. Berdasarkan data observasi aktivitas guru dalam menerapkan model pembelajaran problem solving siklus-1 pertemuan 1 dapat diketahui ada 4 deskriptor yang tidak muncul pada waktu guru mengajar yaitu mengkondisikan siswa untuk siap belajar, memberikan penguatan dan pujian terhadap kegiatan pembelajaran yang telah dilakukan, membimbing siswa menyampaikan kesan dari kegiatan pembelajarn yang telah dilakukan siswa dan mengakhiri kegiatan pembelajaran dengan berdo'a. 
Berdasarkan data observasi aktivitas guru dalam menerapkan model pembelajaran problem solving siklus-1 pertemuan 2 dapat diketahui ada 3 deskriptor yang tidak muncul pada waktu guru mengajar yaitu mengkondisikan siswa untuk siap belajar, memberikan penguatan dan pujian terhadap kegiatan pembelajaran yang telah dilakukan dan mengakhiri kegiatan pembelajaran dengan berdo'a.

Penerapan model pembelajaran problem solving pada siklus-1 pertemuan 1 memperoleh prosentase 87,50\%. Pada siklus-1 pertemuan 2 memperoleh prosentase $90,63 \%$. Rata-rata prosentase kesesuaian guru menerapkan model pembelajaran problem solving siklus-1 yaitu 89,07\%. Penerapan model pembelajaran problem solving siklus-1 masih perlu ditingkatkan. perlu ditingkatkan pada siklus-2. Hal itu karena pada siklus-1 penerapan model pembelajaran problem solving belum optimal.

Pada siklus- 1 pertemuan 1 siswa sudah ada yang aktif selama mengikuti kegiatan pembelajaran, kerjasama siswa dalam memecahkan masalah dalam mengerjakan Lembar Kegiatan Kelompok sudah tampak dan ketepatan siswa yang meliputi ketepatan siswa dalam menggunakan pengungkit, melakukan percobaan dan memecahkan masalah sudah ada meskipun prosentase ketuntasan aktivitas belajar klasikalnya masih rendah $<70 \%$. Siswa selama mengikuti kegiatan pembelajaran sudah ada semangat walaupun sedikit. Siswa sangat senang pada waktu melakukan percobaan menggunakan pengungkit untuk memecahkan masalah yang berkaitan dengan pengungkit. Walaupun masih ada beberapa siswa yang mengobrol dengan temannya pada waktu mengikuti kegiatan pembelajaran.

Aktivitas belajar siswa pada siklus-1 pertemuan 2 masih perlu ditingkatkan. Keaktifan siswa, kerjasama siswa pada waktu memecahkan masalah dalam mengerjakan Lembar Kegiatan Kelompok dan ketepatan siswa yang meliputi ketepatan siswa dalam menggunakan pengungkit, melakukan percobaan dan memecahkan masalah sudah meningkat dari siklus-1 pertemuan 1 meskipun prosentase ketuntasan aktivitas belajar klasikalnya belum mencapai $70 \%$.

Nilai Hasil belajar siswa siklus-1 diperoleh dari nilai rata-rata hasil belajar siswa siklus-1 pertemuan 1 dan 2. Prosentase ketuntasan hasil belajar klasikal siklus-1 yaitu 63,16\% dengan nilai rata-rata hasil belajar kelas 68,11. Nilai tertinggi hasil belajar siswa pada siklus-1 yaitu 82. Sedangkan nilai terendah hasil belajar siswa pada siklus-1 yaitu 54. Hasil belajar siswa siklus-1 dapat dikategorikan cukup. Hasil belajar siswa siklus-1 perlu diperbaiki pada siklus-2.

\section{Refleksi}

Berdasarkan observasi terhadap pelaksanaan kegiatan pembelajaran pada siklus-1 masih perlu ditingkatkan. Prosentase kesesuaian guru menerapkan model pembelajaran problem solving pada siklus-1 masih dapat ditingkatkan pada siklus2 sehingga prosentase aktivitas belajar klasikal dan prosentase hasil belajar klasikal dapat meningkat pada siklus-2. Prosentase aktivitas belajar klasikal dan prosentase hasil belajar siklus-1 masih < 70\%. Oleh sebab itu, materi pembelajaran pada siklus-1 diulangi pada pelaksanaan kegiatan pembelajaran siklus-2. 


\section{Siklus II}

Pada siklus-2 terdapat beberapa tahapan yang dilakukan peneliti. Tahapan yang dilakukan pada siklus-2 antara lain planning (perencanaan), acting and observing (tindakan dan pengamatan), reflecting (refleksi) dan revise plan (perbaikan rencana).

\section{Perencanaan}

Siklus-2 dilakukan untuk memperbaiki kekurangan pelaksanaan kegiatan pembelajaran yang ada pada siklus-1. Perencanaan yang dilakukan pada siklus-2 harus memperhatikan perbaikan rencana pada siklus-1 yang telah disesuaikan untuk mengatasi kekurangan pelaksanaan kegiatan pembelajaran pada siklus-1.

Perencanaan yang dilakukan peneliti membuat Rencana Pelaksanaan Pembelajaran (RPP), menyiapkan media pembelajaran pengungkit, membuat Lembar Kegiatan Kelompok (LKK), membuat soal evaluasi dan menyiapkan instrumen penelitian. Rencana Pelaksanaan Pembelajaran (RPP) yang dibuat peneliti mencerminkan kegiatan siswa sesuai dengan langkah-langkah model pembelajaran problem solving meliputi (1) merumuskan masalah, (2) menganalisis masalah, (3) merumuskan hipotesis, (4) mengumpulkan data, (5) pengujian hipotesis, (6) merumuskan rekomendasi pemecahan masalah. Instrumen penelitian yang dibuat peneliti pada siklus-2 meliputi pedoman observasi, pedoman wawancara, pedoman dokumentasi, soal evaluasi dan catatan lapangan.

\section{Pelaksanaan}

Tindakan ini melalui beberapa proses seperti siklus-1, meliputi pra kegiatan, kegiatan awal, kegiatan inti, kegiatan akhir. Proses pada siklus-2 ini dipecah menjadi 2 pertemuan.

\section{Pengamatan}

Penerapan model pembelajaran problem solving dapat dilihat pada lembar observasi aktivitas guru dalam menerapkan model pembelajaran problem solving, pedoman wawancara dan catatan lapangan. Pada pelaksanaan kegiatan pembelajaran pada siklus-2 pertemuan 1, 2 dan 3, model pembelajaran problem solving dapat diterapkan dengan baik sekali. Guru secara umum sudah dapat menerapkan model pembelajaran problem solving sesuai dengan langkah-langkah model pembelajaran problem solving.

Penerapan model pembelajaran problem solving pada siklus- 2 pertemuan 1 memperoleh prosentase $100 \%$. Pada siklus-2 pertemuan 2 memperoleh prosentase $100 \%$. Pada siklus-2 pertemuan 3 memperoleh prosentase $100 \%$. Ratarata prosentase kesesuaian guru menerapkan model pembelajaran problem solving siklus-2 yaitu 100\%. Penerapan model pembelajaran problem solving siklus-2 dapat dikategorikan baik sekali.

Pada siklus-2 pertemuan 1, sebagian besar siswa sudah aktif menjawab pertanyaan dan mengemukakan pendapatnya. Sebagaian besar siswa mau membantu temannya mengerjakan LKK. Siswa yang mengemukakan pendapatnya dengan penuh semangat walaupun ada beberapa pendapat siswa yang kurang tepat.

Pada siklus-2 pertemuan 2, sebagian besar siswa sudah aktif menjawab pertanyaan dan mengemukakan pendapatnya. Siswa mau membantu temannya 
mengerjakan LKK. Ketepatan siswa memecahkan masalah juga mengalami peningkatan dari siklus-2 pertemuan 1 .

Aktivitas belajar siswa pada siklus-2 pertemuan 3 sudah baik sekali. Siswa sudah aktif menjawab pertanyaan dan mengemukakan pendapatnya. Kerjasama siswa dalam memgerjakan LKK sudah baik sekali. Selama mengerjakan LKK, suasana kelas sudah kondusif. Ketepatan siswa memecahkan masalah juga tepat.

Data nilai aktivitas belajar siswa siklus-2 merupakan rata-rata nilai aktivitas belajar siswa siklus-2 pertemuan 1, 2 dan 3. Data nilai aktivitas belajar siswa dapat dilihat dari pedoman aktivitas belajar siswa, pedoman wawancara dan catatan lapangan.

Berdasarkan observasi pada kegiatan pembelajaran siklus-2 dapat diketahui bahwa prosentase kesesuaian guru menerapkan model pembelajaran problem solving, prosentase aktivitas belajar klasikal dan prosentase hasil belajar klasikal $\geq 70 \%$. Prosentase kesesuaian guru menerapkan model pembelajaran problem solving sudah mengalami peningkatan dari siklus-1. Aktivitas belajar siswa sudah mengalami peningkatan yang bagus. Siswa sudah aktif mengikuti kegiatan pembelajaran. Siswa juga sudah mampu bekerja sama dengan temannya. Selain itu siswa dapat memecahkan masalah yang berkaitan dengan berbagai golongan pengungkit yang dapat membuat pekerjaan lebih mudah dan cepat yang terdapat dalam LKK dengan tepat. Hasil belajar siswa mengerjakan soal evaluasi juga mengalami peningkatan dari siklus-1. Hal itu menunjukkan penerapan model pembelajaran problem solving dapat meningkatkan aktivitas dan hasil belajar siswa kelas V SDN 2 Gembleb,Kecamatan Pogalan Kabupaten Trenggalek

\section{Refleksi}

Prosentase kesesuaian guru menerapkan model pembelajaran problem solving, prosentase aktivitas belajar klasikal dan prosentase hasil belajar klasikal siklus- $2 \geq 70 \%$. Nilai rata-rata aktivitas belajar kelas dan nilai rata-rata hasil belajar kelas $\geq 70$. Berdasarkan temuan tersebut, maka pada siklus-2 penelitian tindakan kelas ini dapat diakhiri dan tidak ada perbaikan rencana.

\section{KESIMPULAN}

Berdasarkan hasil penelitian tindakan kelas yang telah dilakukan, dapat diperoleh kesimpulan sebagai berikut, (1) Penerapan model pembelajaran problem solving pada pembelajaran IPA materi pokok pengungkit siswa kelas V SDN 2 Gembleb Kecamatan Pogalan Kabupaten Trenggalek dapat diterapkan dengan baik sekali dan berhasil merubah kegiatan pembelajaran yang bersifat teacher centered menjadi student centered. Guru dapat menerapkan model pembelajaran problem solving pada pembelajaran IPA sesuai dengan langkah model pembelajaran problem solving meliputi (a) merumuskan masalah, (b) menganalisis masalah, (c) merumuskan hipotesis, (d) mengumpulkan data, (e) pengujian hipotesis, (f) merumuskan rekomendasi pemecahan masalah. Penerapan model pembelajaran problem solving pada pembelajaran IPA materi pokok pengungkit siswa kelas V SDN 2 Gembleb Kecamatan Pogalan Kabupaten Trenggalek mengalami peningkatan dari siklus-1 yaitu $89,07 \%$ meningkat pada siklus-2 menjadi 100\%, (2) Penerapan model pembelajaran problem solving pada pembelajaran IPA materi pokok pengungkit siswa kelas V SDN 2 Gembleb 
Kecamatan Pogalan Kabupaten Trenggalek dapat meningkatkan aktivitas belajar siswa. Siswa yang sebelumnya pasif menjadi aktif mengikuti kegiatan pembelajaran. Kerjasama siswa mengalami peningkatan. Siswa dapat menggunakan media pembelajaran yang termasuk pengungkit, melakukan percobaan dan memecahkan masalah yang berkaitan dengan berbagai golongan pengungkit yang dapat membuat pekerjaan lebih mudah dan lebih cepat dalam LKK dengan tepat. Aktivitas belajar siswa mengalami peningkatan dari siklus-1 ke siklus-2. Prosentase ketuntasan aktivitas belajar klasikal siklus-1 yaitu 52,63\% dengan nilai rata-rata aktivitas belajar kelas yaitu 67,76. Prosentase ketuntasan aktivitas belajar klasikal siklus-2 yaitu $100 \%$ dengan nilai rata-rata aktivitas belajar kelas yaitu 87,72, (3) Penerapan model pembelajaran problem solving pada pembelajaran IPA materi pokok pengungkit siswa kelas V SDN 2 Gembleb Kecamatan Pogalan Kabupaten Trenggalek dapat meningkatkan hasil belajar siswa. Prosentase ketuntasan hasil belajar klasikal pra tindakan yaitu 21,05\% dengan nilai rata-rata hasil belajar kelas yaitu 50,63. Prosentase ketuntasan hasil belajar klasikal siklus-1 yaitu 63,16\% dengan nilai rata-rata hasil belajar kelas yaitu 68,11. Prosentase ketuntasan hasil belajar klasikal siklus-2 yaitu $100 \%$ dengan nilai rata-rata hasil belajar kelas yaitu 90,04.

\section{SARAN}

Berdasarkan hasil penelitian tindakan kelas ini, peneliti memberikan saran bagi guru dan peneliti selanjutnya jika menerapkan atau mengadakan penelitian tindakan kelas dengan menerapkan model pembelajaran problem solving sebaiknya memperhatikan kesesuaian materi pembelajaran dengan materi pembelajaran yang menuntut pemecahan masalah, keluasan materi pembelajaran misalnya tidak hanya memecahkan masalah yang berkaitan dengan pengungkit saja tetapi dapat juga memecahkan masalah yang berkaitan dengan bidang miring dan katrol, memperhatikan alokasi waktu misalnya mengukur waktu penggunaan alat misalnya pengungkit terlebih dahulu sebelum melakukan kegiatan pembelajaran dengan menerapkan model pembelajaran problem solving agar alokasi waktu yang tersedia sesuai dan memecahkan masalah satu persatu sampai selesai.

\section{DAFTAR RUJUKAN}

Akbar, Sa'dun. 2010. Penelitian Tindakan Kelas: Filosofi, Metodologi \& Implementasi (Edisi Revisi). Yogyakarta: Cipta Media Aksara.

Arikunto, Suharsimi. 2002. Prosedur Penelitian Suatu Pendekatan Praktis. Jakarta: Rineka Cipta.

Azmiyawati, Choiril, dkk. 2008. IPA 5 Salingtemas untuk Kelas V SD/MI (BSE). Jakarta: Pusat Perbukuan Depdiknas.

Depdiknas. 2006. Kurikulum KTSP 2006. Standar Kompetensi dan Kompetensi Dasar Ilmu Pengetahuan Alam untuk Sekolah Dasar. Jakarta: Depdiknas.

Dewiki, Santi \& Yuniati P. K. H., Sri. 2006. Ilmu Alamiah Dasar. Jakarta: Universitas Terbuka.

Dimyati \& Mudjiono. 2006. Belajar dan Pembelajaran. Jakarta: PT Rineka Cipta. Hamalik, Oemar. 2010. Proses Belajar Mengajar. Jakarta: PT Bumi Aksara. Kurnia, Inggridwati, dkk. 2007. Bahan Ajar Cetak: Perkembangan Belajar Peserta Didik. Jakarta: Depdiknas. 
Mashudi, Toha, dkk. 2010. Buku Petunjuk Teknis Praktik Pengalaman Lapangan Program Strata 1 (S1) PGSD jurusan KSDP FIP. Malang: Universitas Negeri Malang.

Muharam, Aris \& Rositawaty, S. 2008. Senang Belajar Ilmu Pengetahuan Alam untuk Kelas V Sekolah Dasar/Madrasah Ibtidaiyah (BSE). Jakarta: Pusat Perbukuan Depdiknas.

Nasution. 2002. Pendidikan IPA di SD. Jakarta: Universitas Terbuka. 